Check for updates

Cite this: RSC Adv., 2018, 8, 29301

\title{
A novel and practical synthesis of CAT3: a phenanthroindolizidine alkaloid with potential in treating glioblastoma $\uparrow$
}

\author{
Ru-Bing Wang, (D) Hai-Ning Lv, Shan-Shan Zhu, Xiao-Dong Ren, (DD Song Xu, \\ Shuang-Gang Ma, Yun-Bao Liu, Jing $\mathrm{Qu}^{*}$ and Shi-Shan Yu*
}

CAT3, one of the (+)-deoxytylophorinine-based phenanthroindolizidine alkaloids, is a promising therapeutic agent for the treatment of hedgehog $(\mathrm{Hh})$-driven glioblastoma and is currently being evaluated in preclinical studies. In this paper, a novel and practical synthetic route for CAT3 was firstly demonstrated with $10 \%$ overall yield in 11 steps and has been successfully validated for pilot-plant scale preparation. Investigation of the substitution at the 3-position of phenanthrene revealed that the electron-donating functionality can well preserve the $S$ configuration. In particular, the excellent enantiomeric excess of CAT3 ( $\geq 99 \%$ ee) was achieved by introducing the strongly electron-donating tert-butyldimethylsilyl (TBS) group.

Received 29th May 2018

Accepted 13th July 2018

DOI: 10.1039/c8ra04511a

rsc.li/rsc-advances

and (13aS)-3-pivaloyloxyl-6,7-dimethoxyphenanthro[9,10- $b]$ indolizidine (CAT3) was designed and synthesized as the prodrug of PF403 (Fig. 1). A series of preclinical studies has proven that CAT3 is a promising therapeutic agent against hedgehog (Hh)-driven GBM. ${ }^{10,12}$ Although the structure of CAT3 only differs slightly from that of CAT, the synthesis of which has been accomplished in several total syntheses, ${ }^{13-15}$ the mutigram synthesis of CAT3 is still challenging. A main problem lies in the completely different starting materials due to the methoxy and pivaloyoxy group for CAT and CAT3, respectively, used in the synthesis. When the same synthetic strategy of CAT was used to synthesize CAT3, ${ }^{13-15}$ it did not work after attempting multiple times in the past. This challenge, together with its excellent potency for GBM, stimulated us to investigate a novel and efficient synthetic route for CAT3.

(+)-Deoxytylophorinine (CAT) was isolated from the Tylophora atrofolliculata and Tylophora ovata and showed significant anticancer properties in vivo with its ability to well penetrate the blood brain barrier, ${ }^{8-11}$ while serious damage on gastrointestine was also observed. In the study of its metabolic products in vivo, (13as)-3-hydroxyl-6,7-dimethoxyphenanthro $[9,10-b]$ indolizidine (PF403, Fig. 1) was found to possess excellent antiproliferative activity with the $\mathrm{IC}_{50}$ value less than $0.01 \mathrm{nM}$ in multiple cancer cell lines in vitro. ${ }^{\mathbf{1 0 - 1 2}}$ However, the excellent data in vitro cannot be reflected to its data in vivo probably due to its poor pharmacokinetic properties. To address this issue, the prodrug strategy was employed herein

State Key Laboratory of Bioactive Substance and Function of Natural Medicines, Institute of Materia Medica, Chinese Academy of Medical Sciences, Peking Union Medical College, Beijing 100050, China. E-mail: yushishan@imm.ac.cn; qujing@ imm.ac.cn; Fax: +86-10-63017757

$\dagger$ Electronic supplementary information (ESI) available. See DOI:

\section{Results and discussion}

Strategically, CAT3 can be easily synthesized from acylation of PF403. Therefore, the efficient synthesis of PF403 is a key question. Takashi and coworkers disclosed the synthesis of PF403 starting from 4-benzyloxybenzaldehyde and 2-(3,4-dimethoxyphenyl)acetic acid with $10.8 \%$ yield in 13 steps, ${ }^{\mathbf{1 6 , 1 7}}$ which

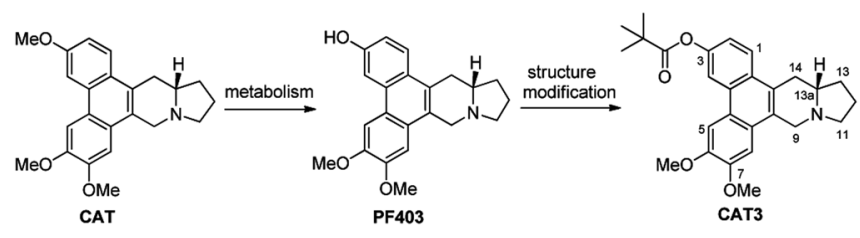

Fig. 1 The development process of the preclinical drug CAT3. 
was the first meaningful synthetic route. However, photoinduced electron cyclization reaction was used to construct the phenanthrene ring, and it was not efficient for large-scale preparation. ${ }^{18}$ PF403 was also successfully prepared in 16 steps in our previous work, but the route was very tedious. ${ }^{15}$ Moreover, it has been demonstrated that it is only applicable for small-amount synthesis. When we tried multigram synthesis, the yield decreased to as low as $2 \%$, making it unacceptable for the large-scale preparation of CAT3.

Thus it is necessary to develop a novel synthesis of PF403. The retrosynthetic analysis was illustrated in scheme 1. We envisioned that PF403 could be accessible from the intermediate $\mathbf{A}$, which could be readily made by reduction and protection from $\mathbf{B}$. It was envisaged that $\mathbf{B}$ could be assembled from compound $\mathbf{C}$ and $\mathbf{D}$ by a substitution reaction.

Based on our retrosynthetic analysis, the synthesis of PF403 commenced with the known compound $\mathbf{1}$, which was obtained using our reported method in 6 steps. ${ }^{15}$ The ester 2 was easily prepared from the condensation of $\mathbf{1}$ with commercially available methyl L-prolinate hydrochloride. Compound 3, which was expected to produce phenanthroindolizidine by eliminating one molecule of $\mathrm{H}_{2} \mathrm{O}$, was easily obtained by reducing 2 with diisobutylaluminum hydride. ${ }^{19}$ However, multiple attempts to construct the indolizidine ring from 3 in one step failed according to literature, ${ }^{20,21}$ even if we tried to convert the hydroxy group to a better leaving group such as MsO-, TfO- or TsO-. Except compound 1, other different substitutions on 3position was tried, such as TBSO- and HO-, but both result were disappointed. Thus the preparation of PF403 via this route proved probably impracticable (Scheme 2).

We deduce that there are two probable pathways starting from 3 under the acid condition to construct phenanthroindolizidine. Theoretically, the route should work well if the aromatic electron at 10-position of phenanthrene ring attacks carbocation to generate phenanthroindolizidine via pathway 1 . However, identification of the chlorinated compound 5 suggests that the carbocation, which probably arised from transition state 4 with the aid of the nitrogen lone-pair electrons, appears to favor the formation of the nitrogen-containing three-membered ring structure as a transition state via pathway 2 (Scheme 3).

After multiple attempts, we eventually found a novel and practical synthetic route to produce CAT3 in 11 steps (Scheme 4). The condensation between 2-(3,4-dimethoxyphenyl)acetic

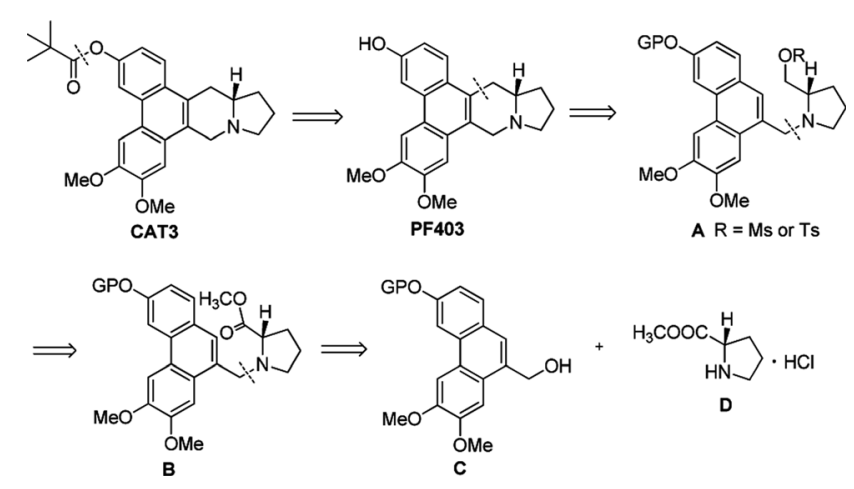

Scheme 1 The retrosynthetic analysis of CAT3.

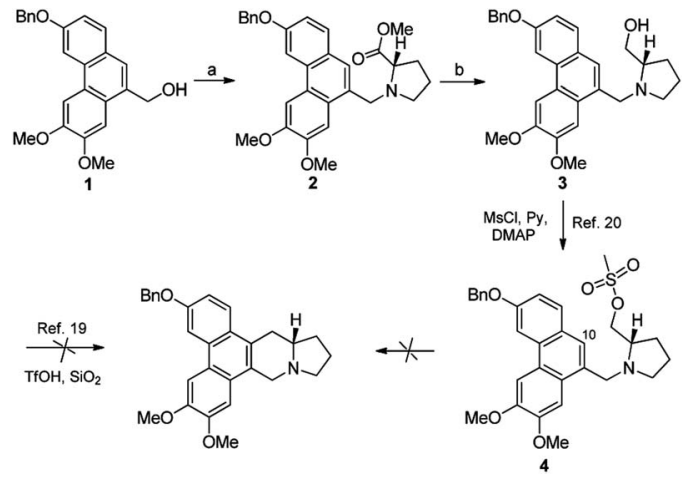

Scheme 2 A simple synthetic route firstly designed for PF403. Reagents and conditions: (a) $\mathrm{PPh}_{3}$, imidazole, $\mathrm{I}_{2}$, DCM, r.t., then methyl L-prolinate hydrochloride, imidazole, r.t.; (b) DIBAL-H, DCM. $0{ }^{\circ} \mathrm{C} ; 40 \%$ for two steps.

acid and 4-hydroxybenzaldehyde gave compound 6 in almost quantitative yield, which was confirmed by difference NOE spectrum as cis-configuration (see ESI $\dagger$ ). Compound 9 was prepared in $50 \%$ overall yield in three steps, including the scroll coupling in the presence of $\mathrm{FeCl}_{3}$, esterification in methanol with con. $\mathrm{H}_{2} \mathrm{SO}_{4}$, substitution of $3-\mathrm{OH}$ with tert-butyldimethylsilyl chloride (TBSCl). The key intermediate $\mathbf{1 0}$ was achieved in $95 \%$ yield by the reduction of 9 with diisobutylaluminum hydride, which was transformed to $\mathbf{1 1}$ in $50 \%$ yield through a reaction sequence including iodine substitution, nucleophilic substitution with L-glutamic acid dimethyl ester hydrochloride, and subsequent hydrolysis. After formation of $\mathbf{1 2}$ in $80 \%$ yield by Friedel-Crafts reaction from 11, its 3-position hydroxyl group was again protected by TBS to give 13 in $85 \%$ yield. The 14position carbonyl of 13 was then reduced to compound 14 in $80 \%$ yield, in which the lactam carbonyl group was further reduced to methylene in 95\% yield, and PF403 was successfully synthesized till now. After PF403 in hand, we firstly tried to

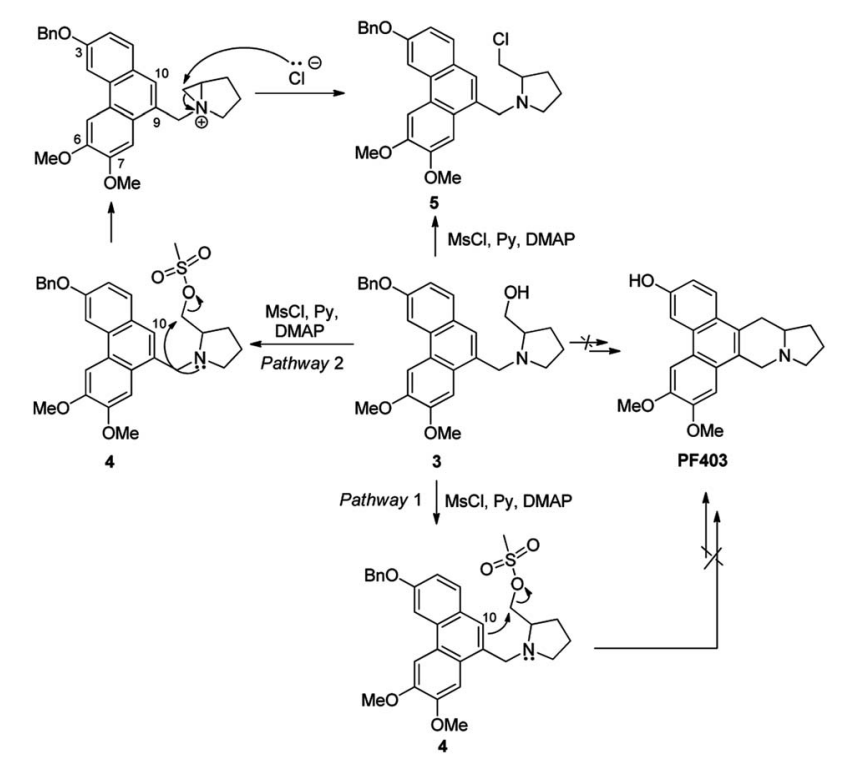

Scheme 3 A plausible mechanism explaining the failure in constructing the phenanthroindolizidine. 

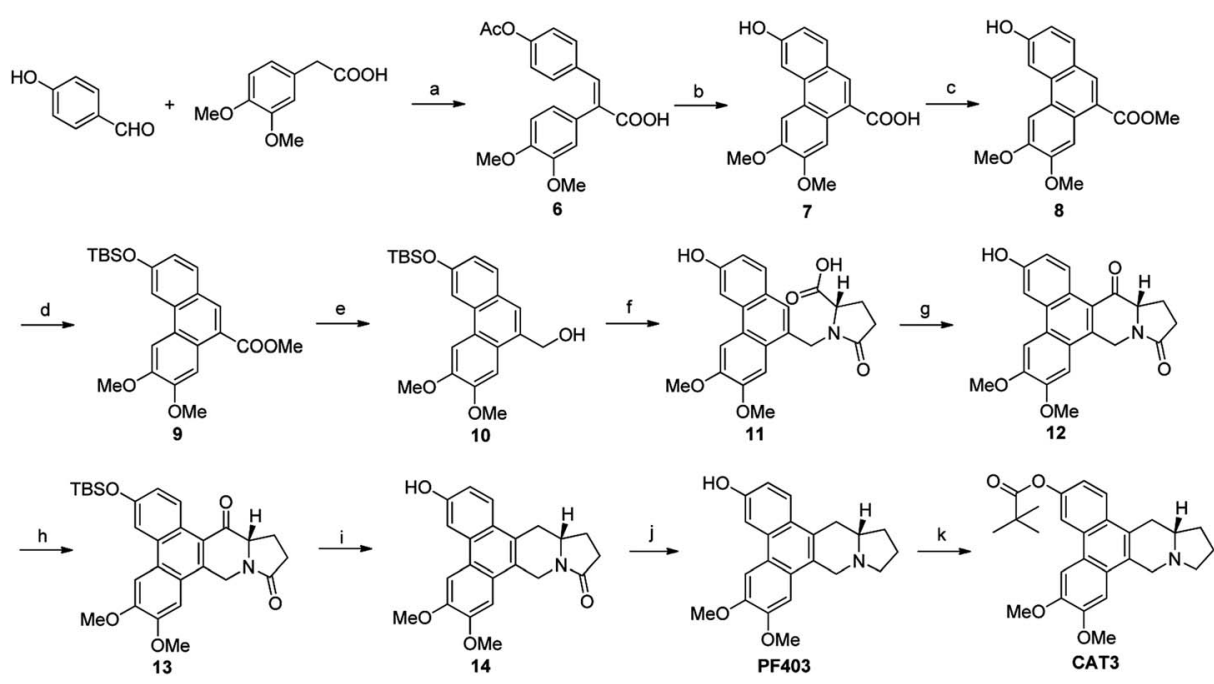

Scheme 4 Reagents and conditions for the large-scale preparation route of CAT3: (a) $\mathrm{Ac}_{2} \mathrm{O}$, $\mathrm{Et}_{3} \mathrm{~N}$, reflux; (b) FeCl $, m-\mathrm{CPBA}, \mathrm{TFA}, \mathrm{r} . t . ;$ (c) $\mathrm{MeOH}$, $\mathrm{H}_{2} \mathrm{SO}_{4}$, reflux; (d) TBSCl, imidazole, DCM, r.t.; $50 \%$ in four steps; (e) DIBAL-H, DCM. $0{ }^{\circ} \mathrm{C}$ to r.t., $95 \%$; (f) i: Nal, TMSCl, then L-dimethyl glutamate, $\mathrm{K}_{2} \mathrm{CO}_{3}$, r.t.; ii: $5 \% \mathrm{HAc}$, r.t.; iii: $\mathrm{NaOH}, \mathrm{CH}_{3} \mathrm{OH}$, r.t., then $\mathrm{HCl}$; $55 \%$; (g) TFAA, r.t., then $\mathrm{BF}_{3}-\mathrm{Et}_{2} \mathrm{O}$, reflux, $85 \%$; (h) TBSCl, imidazole, DMF, r.t., $85 \%$; (i) $\mathrm{NaBH}_{4}, \mathrm{DCM}-\mathrm{MeOH}$, then $\mathrm{Et}_{3} \mathrm{SiH}, \mathrm{BF}_{3}-\mathrm{Et}_{2} \mathrm{O}$, r.t., 80\%; (j) Red-Al, THF, r.t., 95\%; (k) pivalic anhydride, Et ${ }_{3} \mathrm{~N}, \mathrm{DMAP}, \mathrm{DCM}, \mathrm{r.t.}, 70 \%$.

prepare CAT3 by acylation of PF403 using pivaloyl chloride. However, a main by-product chlorinated substitution on 4position of CAT3 was produced, which was difficult to be separated because of its polarity almost the same as CAT3. At last, pivaloyl chloride was replaced by pivalic anhydride and CAT3 was smoothly achieved with a yield as high as $70 \%$ avoiding the by-product. In general, there are several aspects of advantages for this route as follows: (1) the conventional design for the synthesis of $\mathbf{6}$ is broken so that no protection step is required for 4-hydroxybenzaldehyde, thus leading to a shorter synthesis; (2) the operation and post treatment of the reactions in this route are easy and convenient, which also result in a high overall yield (10\%), and no traditional column chromatography is used; (3) pilot-scale preparation has been achieved for this route with cheap reagents and materials used, indicating that it is probably an economical route for large-scale synthesis; (4) all the chiral intermediates and products are prepared in high optical purity ( $\geq 99 \%$ ee), which is vital for a drug candidate.

It should be noted that compound 14 can be synthesized in one step from 12 with high yield (Scheme 5). However, the optical purity of CAT3 from this approach was not satisfactory. We studied all the chiral intermediates and noticed that the optical purity obviously decreased when the 14-position ketone of compound $\mathbf{1 2}$ was reduced to the hydroxyl group. In order to figure it out, a batch of experiments were performed. As a common sense, we first focused our efforts on the solvent and
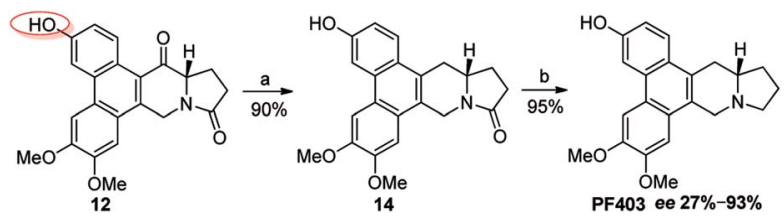

Scheme 5 Reagents and conditions for the synthesis of PF403 starting from 12: (a) $\mathrm{NaBH}_{4}$, then $\mathrm{Et}_{3} \mathrm{SiH}, \mathrm{BF}_{3}-\mathrm{Et}_{2} \mathrm{O}$, r.t.; (b) Red-Al, THF, r.t. temperature used in this step. Different kinds of solvents or/and their combination were tested, such as diethylene glycol dimethyl, tetrahydrofuran, methanol, ethanol, dichloromethane and so on. Meanwhile, we tried the reaction at different temperatures, including $-20{ }^{\circ} \mathrm{C}, 0{ }^{\circ} \mathrm{C}$ and $20{ }^{\circ} \mathrm{C}$. Unfortunately, the results were unsatisfactory $(27-93 \%$ ee, Scheme 5) in all these cases. Then we turned to modify the 3position of compound 12. Three different substitutes were selected and compared, including the free hydroxyl group, and the hydroxyl protected with the electron-donating benzyl and electron-withdrawing acetyl group. The best enantiomeric excess was obtained when 3-position hydroxyl was protected as benzyl ether (95-98\% ee, Scheme 6) while the worst result obtained when protected as acetyl ester (10-50\% ee, Scheme 7). Thus it can be preliminarily inferred that substitution on 3position is related with the enantiomeric excess of the final product, and stronger electron-donating ability may further increase the optical purity of the product. As we expect, excellent enantiomeric excess was achieved when the 3-position hydroxyl
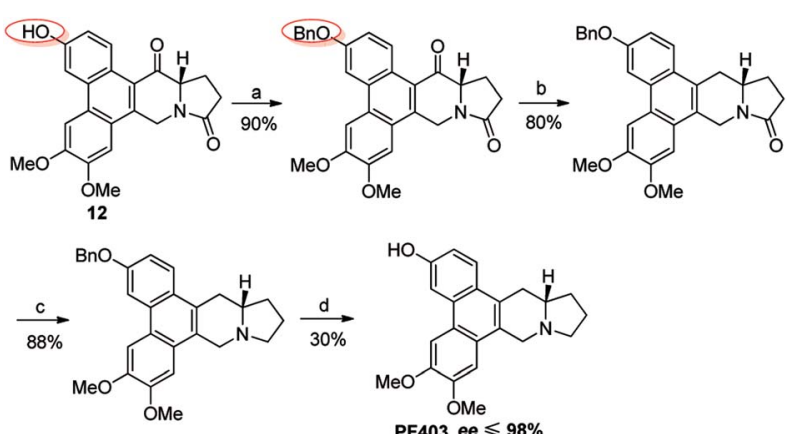

Scheme 6 Reagents and conditions for the synthesis of PF403 starting from 12 with benzyl substitution at 3-position: (a) $\mathrm{BnBr}, \mathrm{K}_{2} \mathrm{CO}_{3}$, acetone, reflux; (b) $\mathrm{NaBH}_{4}$, then $\mathrm{Et}_{3} \mathrm{SiH}, \mathrm{BF}_{3}-\mathrm{Et}_{2} \mathrm{O}$, r.t.; (c) Red-Al, THF, r.t.; (d) $\mathrm{Pd}-\mathrm{C}, \mathrm{H}_{2}, \mathrm{MeOH}$, r.t. 


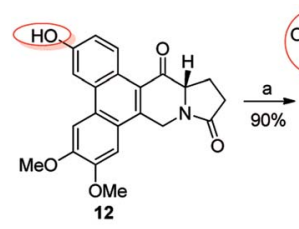

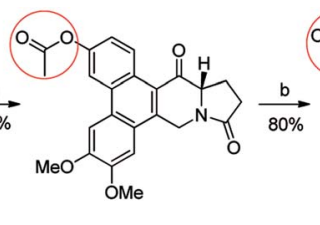<smiles></smiles>

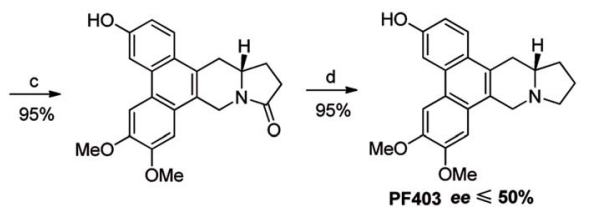

Scheme 7 Reagents and conditions for the synthesis of PF403 starting from 12 with acetyl substitution at 3-position: (a) $\mathrm{Ac}_{2} \mathrm{O}, \mathrm{TEA}, \mathrm{DMAP}$, $\mathrm{DCM}$, r.t.; (b) $\mathrm{NaBH}_{4}$, then $\mathrm{Et}_{3} \mathrm{SiH}, \mathrm{BF}_{3}-\mathrm{Et}_{2} \mathrm{O}$, r.t.; (c) $\mathrm{NaOH}, \mathrm{CH}_{3} \mathrm{OH}$, r.t., then $\mathrm{HCl}$; (d) Red-Al, THF, r.t.

was protected by the strong electron-donating TBS group ( $\geq 99 \%$ ee, Scheme 8 ). We deduce that the electron-donating group at 3-position, which appears far from the ketone at C14 in the plane structure, has a remote control on the stereochemistry of the phenanthroindolizidine moiety in favor of the formation of the $S$-configured center. The yields and ee values generated from different substitutions were illustrated in Schemes 5-8 and Table 1.

\section{Experimental}

\section{General methods}

All the reactions sensitive to air or moisture were carried out under argon atmosphere in anhydrous solvents. The purchased extra dry Tetrahydrofuran (THF) with the resealable package was used directly. Thin layer chromatography (TLC) was performed using glass precoated silica gel GF254 plates. Spots were visualized under $254 \mathrm{~nm}$ or $365 \mathrm{~nm}$ UV light or colored by $1 \%$ $\mathrm{KMnO}_{4}$ in $5 \% \mathrm{NaCO}_{3}$ aqueous solution. NMR spectra were obtained on Bruker-400 MHz and Bruker-500 MHz spectrometers. Chemical shifts are reported in $\delta(\mathrm{ppm})$ relative to solvent peaks. High-resolution electrospray ionization mass spectra (HRESIMS) data were obtained on micromass Autospec-Ultima ETOF spectrometer. High performance liquid chromatography
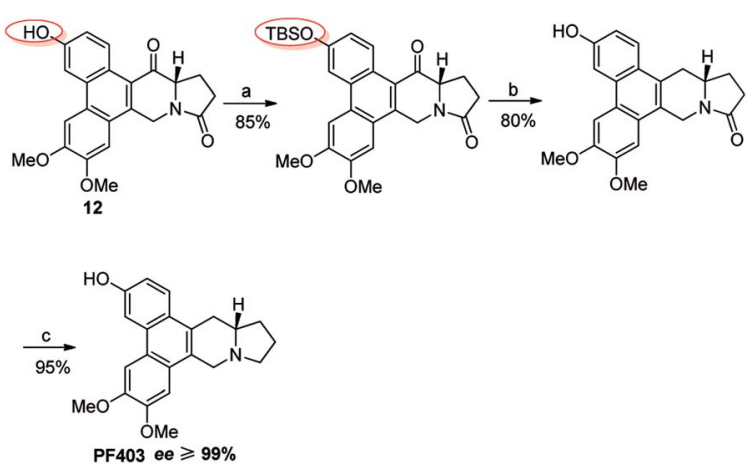

Scheme 8 Reagents and conditions for the synthesis of PF403 starting from 12 with TBS substitution at 3-position: (a) TBSCl, imidazole, DMF, r.t.; (b) $\mathrm{NaBH}_{4}$, then $\mathrm{Et}_{3} \mathrm{SiH}, \mathrm{BF}_{3}-\mathrm{Et}_{2} \mathrm{O}$, r.t.; (c) Red-Al, THF, r.t.
Table 1 The ee and yield of the final product from the different synthetic route

\begin{tabular}{lllll}
\hline & \multicolumn{4}{l}{ Substitution at 3-position of compound 12 } \\
\cline { 2 - 5 } & HO & BnO & TBSO & AcO \\
\hline ee & $27-93 \%$ & $95-98 \%$ & $\geq 99 \%$ & $10-50 \%$ \\
Yield & $13.2 \%$ & $2.9 \%$ & $10.0 \%$ & $10.1 \%$ \\
\hline
\end{tabular}

(HPLC) was performed the HPLC system was equipped with a UV-vis detector (G1315C/D), an Agilent 1200 series G1322A IV pump and software for process control and data handling (Agilent ChemStation for LC 3D Systems) equipping an GL Intersil ODS column $(250 \times 10 \mathrm{~mm}, 5 \mu \mathrm{m})$. UV spectra were measured on a JASCO V650 spectrophotometer. IR spectra were recorded on a Nicolet 5700 FT-IR microscope instrument (FT-IR microscope transmission).

\section{(S)-(1-((3-(Benzyloxy)-6,7-dimethoxyphenanthren-9-yl)methyl) pyrrolidin-2-yl)methanol (3)}

To a stirring solution of imidazole $(90 \mathrm{mg}, 1.32 \mathrm{mmol})$ and triphenylphosphine $(267 \mathrm{mg}, 1.02 \mathrm{mmol})$ in DCM $(15 \mathrm{ml})$ was added iodine $(214 \mathrm{mg}, 0.84 \mathrm{mmol})$. After stirring for $10 \mathrm{~min}$ at room temperature, compound $1(224 \mathrm{mg}, 0.6 \mathrm{mmol})$ was added. After completion of the substitution, imidazole $(122 \mathrm{mg}, 1.8$ mmol) and methyl L-prolinate hydrochloride (198 mg, 1.2 $\mathrm{mmol}$ ) was added to the stirring reaction in sequences. After completion of the reaction, it was quenched by the addition of the aqueous solution of saturated $\mathrm{NH}_{4} \mathrm{Cl}(20 \mathrm{ml})$. The reaction mixture was extracted into dichloromethane $\mathrm{CH}_{2} \mathrm{Cl}_{2}(3 \times 20$ $\mathrm{ml})$. The combined organic layer was washed with brine $(2 \times 30$ $\mathrm{ml}$ ), dried with anhydrous $\mathrm{Na}_{2} \mathrm{SO}_{4}$, and concentrated under vacuum to furnish the residue as crude product (2). To the cooled $\left(-10^{\circ} \mathrm{C}\right)$ solution of the crude product in dry $\mathrm{CH}_{2} \mathrm{Cl}_{2}(30$ $\mathrm{ml}$ ) was added DIBALH (0.8 ml, $1.2 \mathrm{mmol}, 1.5 \mathrm{M}$ in toluene) dropwise under argon, and the reaction mixture was allowed to stir at room temperature for $12 \mathrm{~h}$. Then the reaction mixture was quenched with the solution of seignette salt along with stirring for additional $12 \mathrm{~h}$. The reaction mixture was separated as two layers and the water layer was extracted with dichloromethane $\mathrm{CH}_{2} \mathrm{Cl}_{2}(3 \times 20 \mathrm{ml})$. The combined organic layer was washed with brine $(2 \times 30 \mathrm{ml})$, dried with anhydrous $\mathrm{Na}_{2} \mathrm{SO}_{4}$, and concentrated under vacuum to furnish the crude product, which was purified by PTLC $(\mathrm{DCM} / \mathrm{MeOH}=10 / 1)$ to provide 3 (109 $\mathrm{mg}, 0.24 \mathrm{mmol}$ ) as yellow oil with $40 \%$ yield in two steps. ${ }^{1} \mathrm{H}$ NMR $\left(500 \mathrm{MHz}\right.$, DMSO- $\left.d_{6}\right) \delta 8.15(\mathrm{~s}, 1 \mathrm{H}), 8.03(\mathrm{~s}, 1 \mathrm{H}), 7.93(\mathrm{~s}$, $1 \mathrm{H}), 7.81(\mathrm{~d}, J=8.7 \mathrm{~Hz}, 1 \mathrm{H}), 7.59-7.53(\mathrm{~m}, 3 \mathrm{H}), 7.43$ (d, $J=$ $7.5 \mathrm{~Hz}, 1 \mathrm{H}), 7.41(\mathrm{~d}, J=7.5 \mathrm{~Hz}, 1 \mathrm{H}), 7.36-7.34(\mathrm{~m}, 1 \mathrm{H}), 7.26(\mathrm{dd}, J$ $=8.7,1.7 \mathrm{~Hz}, 1 \mathrm{H}), 5.36(\mathrm{~s}, 2 \mathrm{H}), 4.70-4.67(\mathrm{~m}, 1 \mathrm{H}), 4.62-4.59(\mathrm{~m}$, $1 \mathrm{H}), 4.03(\mathrm{~s}, 3 \mathrm{H}), 3.93(\mathrm{~s}, 3 \mathrm{H}), 3.66-3.61(\mathrm{~m}, 1 \mathrm{H}), 3.51-3.45(\mathrm{~m}$, $2 \mathrm{H}), 2.66-2.59(\mathrm{~m}, 2 \mathrm{H}), 2.25-2.22(\mathrm{~m}, 1 \mathrm{H}), 1.91-1.87(\mathrm{~m}, 1 \mathrm{H})$, $1.61-1.50(\mathrm{~m}, 3 \mathrm{H}) .{ }^{13} \mathrm{C}$ NMR $\left(125 \mathrm{MHz}\right.$, DMSO- $\left.d_{6}\right) \delta 156.9,148.8$, $148.7,137.3,131.5,130.6,129.8,128.8,128.5,128.1,127.9$, 126.5, 125.3, 124.3, 116.1, 106.4, 105.4, 104.2, 69.7, 65.3, 64.9, 59.0, 55.9, 55.3, 54.5, 28.0, 22.5. HRESIMS, $\mathrm{m} / \mathrm{z}$ calculated for $\mathrm{C}_{29} \mathrm{H}_{32} \mathrm{NO}_{4}[\mathrm{M}+\mathrm{H}]^{+}:$458.2331. Found: 458.2338 . 
(S)-1-((3-(Benzyloxy)-6,7-dimethoxyphenanthren-9-yl)methyl)2-(chloromethyl)pyrrolidine (5)

To the cooled $\left(0{ }^{\circ} \mathrm{C}\right)$ solution of $3(55 \mathrm{mg}, 0.12 \mathrm{mmol})$ in dry $\mathrm{CH}_{2} \mathrm{Cl}_{2}(10 \mathrm{ml})$ was added pyridine $(21 \mathrm{mg}, 0.26 \mathrm{mmol})$, DMAP (1.2 $\mathrm{mg}, 0.01 \mathrm{mmol}$ ) and methanesulfonyl chloride. After stirring for $12 \mathrm{~h}$ at room temperature, the reaction was quenched by the addition of the saturated sodium bicarbonate aqueous. The reaction mixture was separated as two layers and the water layer was extracted with dichloromethane $\mathrm{CH}_{2} \mathrm{Cl}_{2}(2 \times 20 \mathrm{ml})$. The combined organic layer was washed with brine $(2 \times 20 \mathrm{ml})$, dried with anhydrous $\mathrm{Na}_{2} \mathrm{SO}_{4}$, and concentrated under vacuum to furnish the crude product, which was purified by PTLC (ethyl acetate/petroleum ether $=1 / 1)$ to provide $5(33 \mathrm{mg}, 0.07 \mathrm{mmol})$ as light yellow oil with $60 \%$ yield. ${ }^{1} \mathrm{H}$ NMR (500 $\mathrm{MHz}, \mathrm{CDCl}_{3}$ ) $\delta 7.93(\mathrm{~d}, J=2.2 \mathrm{~Hz}, 1 \mathrm{H}), 7.92(\mathrm{~s}, 1 \mathrm{H}), 7.83(\mathrm{~s}, 1 \mathrm{H}), 7.76(\mathrm{~d}, J=$ $8.7 \mathrm{~Hz}, 1 \mathrm{H}), 7.56(\mathrm{~d}, J=2.2,1 \mathrm{H}), 7.54(\mathrm{~s}, 1 \mathrm{H}), 7.48(\mathrm{~s}, 1 \mathrm{H}), 7.43$ (d, $J=7.5 \mathrm{~Hz}, 1 \mathrm{H}), 7.41$ (d, $J=7.5 \mathrm{~Hz}, 1 \mathrm{H}), 7.38-7.33(\mathrm{~m}, 1 \mathrm{H})$, 7.25 (dd, $J=8.7,2.2 \mathrm{~Hz}, 1 \mathrm{H}), 5.29$ (s, 2H), 4.10 (s, 3H), 4.05 (s, $3 \mathrm{H}), 3.98-3.92(\mathrm{~m}, 1 \mathrm{H}), 3.85-3.80(\mathrm{~m}, 1 \mathrm{H}), 3.07-3.02(\mathrm{~m}, 1 \mathrm{H})$, 2.70-2.65 (m, 1H), 2.42-2.39 (m, 1H), 2.26-2.21 (m, 1H), 2.122.08 (m, 1H), 1.82-1.77 (m, 1H), 1.70-1.53 (m, 2H), 1.26-1.23 $(\mathrm{m}, 1 \mathrm{H})$. HRESIMS, $m / z$ calculated for $\mathrm{C}_{29} \mathrm{H}_{31} \mathrm{ClNO}_{3}[\mathrm{M}+\mathrm{H}]^{+}$: 476.1992. Found: 476.1996.

\section{(E)-3-(4-Acetoxyphenyl)-2-(3,4-dimethoxyphenyl)acrylic acid} (6)

To a stirring solution of 3, 4-dimethoxyphenyl acetic acid (196 g, $1 \mathrm{~mol}$ ) and 4-hydroxybenzaldehyde (123 g, $1 \mathrm{~mol})$ in acetic anhydride $(400 \mathrm{ml})$ was added triethylamine $(200 \mathrm{ml})$ dropwise and the mixture was refluxed overnight under argon. After completion of the reaction, it was cooled to room temperature and $800 \mathrm{ml}$ water was added. The reaction was stirred for $1 \mathrm{~h}$ and furnished 6 ( $341 \mathrm{~g}, 1 \mathrm{~mol})$ as yellow solid after a sequence of filtration, water washing and drying. ${ }^{1} \mathrm{H}$ NMR $(500 \mathrm{MHz}$, $\left.\mathrm{CD}_{3} \mathrm{OD}\right) \delta 7.78(\mathrm{~s}, 1 \mathrm{H}), 7.08(\mathrm{~d}, J=8.7 \mathrm{~Hz}, 2 \mathrm{H}), 6.93(\mathrm{~d}, J=8.2 \mathrm{~Hz}$, $1 \mathrm{H}), 6.90(\mathrm{~d}, J=8.7 \mathrm{~Hz}, 2 \mathrm{H}), 6.73(\mathrm{~s}, 1 \mathrm{H}), 6.72(\mathrm{dd}, J=8.2$, $2.0 \mathrm{~Hz}, 1 \mathrm{H}), 3.82(\mathrm{~s}, 3 \mathrm{H}), 3.69(\mathrm{~s}, 3 \mathrm{H}), 2.20(\mathrm{~s}, 3 \mathrm{H}) .{ }^{13} \mathrm{C}$ NMR $(125$ $\left.\mathrm{MHz}, \mathrm{CD}_{3} \mathrm{OD}\right) \delta 171.1,170.8,152.6,150.6,150.3,140.1,134.2$, 133.9, 132.6, 129.9, 123.6, 122.6, 114.7, 112.97, 56.4, 56.3, 49.5, 49.3 , 49.2 , 49.0 , 48.8, 48.7, 48.5, 20.9. IR (KBr) $\nu_{\max }=3072,2992$, 2838, 2630, 1768, 1680, 1612, 1514, 1419, 1456, 1369, 1021, 912, $848 \mathrm{~cm}^{-1}$. HRESIMS, $m / z$ calculated for $\mathrm{C}_{19} \mathrm{H}_{18} \mathrm{O}_{6} \mathrm{Na}[\mathrm{M}+\mathrm{Na}]^{+}$: 365.0996. Found: 365.0986 .

\section{Methyl 3-((tert-butyldimethylsilyl)oxy)-6,7-dimethoxy phenanthrene-9-carboxylate (9)}

To a solution of 6 (341 g, $1 \mathrm{~mol})$ and ferric chloride in trifluoroacetic acid (1400 ml) was added dropwise a solution of 3chloroperbenzoic acid (189.8 g, $1.1 \mathrm{~mol})$ in trifluoroacetic acid $(1700 \mathrm{ml})$ below $0{ }^{\circ} \mathrm{C}$ and then stirred for $12 \mathrm{~h}$ at room temperature. After completion of the reaction, a solution of sodium thiosulfate pentahydrate $(20 \mathrm{~g}$ in $100 \mathrm{ml}$ water $)$ was added and then stirred for $30 \mathrm{~min}$. The reaction was evaporated under reduced pressure to afford crude product 7 ( $800 \mathrm{~g})$, which was used for the next step without further purification. To the solution of $7(800 \mathrm{~g})$ in methanol $(2500 \mathrm{ml})$ was added concentrated sulfuric acid $(125 \mathrm{ml})$, and the reaction was refluxed for $12 \mathrm{~h}$. After completion of the reaction, it was quenched by the addition of imidazole (306 g) and was stirred for another $30 \mathrm{~min}$. Then the mixture was concentrated under vacuum to furnish the residue as crude product (8). To the stirring solution of the crude product and imidazole $(238 \mathrm{~g}, 3.5$ $\mathrm{mol})$ in dichloromethane $(2000 \mathrm{ml})$ was added TBSCl (530 g, 3.5 mol). After stirring for $12 \mathrm{~h}$, the produced solid was filtered and the filtrate was washed by brine $(2 \times 2000 \mathrm{ml})$, dried with anhydrous $\mathrm{Na}_{2} \mathrm{SO}_{4}$, and concentrated under vacuum to furnish the residue, which was purified by fast silica column chromatography (PE/EtOAc, $5: 1)$ to give $9(213 \mathrm{~g}, 0.5 \mathrm{~mol})$ as yellow solid with $50 \%$ yield in four steps. Mp $144-146{ }^{\circ} \mathrm{C} ;{ }^{1} \mathrm{H}$ NMR $(500$ $\left.\mathrm{MHz} \mathrm{CDCl}_{3}\right) \delta 8.65(\mathrm{~s}, 1 \mathrm{H}), 8.45(\mathrm{~s}, 1 \mathrm{H}), 7.86(\mathrm{~s}, 1 \mathrm{H}), 7.86(\mathrm{~d}, J=$ $2.2 \mathrm{~Hz}, 1 \mathrm{H}), 7.82(\mathrm{~d}, J=8.6 \mathrm{~Hz}, 1 \mathrm{H}), 7.13(\mathrm{dd}, J=8.6,2.2 \mathrm{~Hz}$, $1 \mathrm{H}), 4.12(\mathrm{~s}, 3 \mathrm{H}), 4.09(\mathrm{~s}, 3 \mathrm{H}), 4.02(\mathrm{~s}, 3 \mathrm{H}), 1.06(\mathrm{~s}, 9 \mathrm{H}), 0.32(\mathrm{~s}$, $6 \mathrm{H}), 0.07$ (s, 4H). ${ }^{13} \mathrm{C}$ NMR (125 MHz, $\left.\mathrm{CDCl}_{3}\right) \delta$ 168.3, 156.6, $149.9,148.9$, 133.6, 131.9, 131.4, 125.0, 124.9, 124.7, 121.9, 120.8, 111.3, 106.9, 103.2, 55.95, 55.90, 52.1, 25.9, 18.5, -4.0. IR $(\mathrm{KBr}) \nu_{\max }=3120,3004,2951,2857,1708,1617,1520,1469$, 1421, 1258, 1208, 1113, 1033, 992, 938, 910, 832, $778 \mathrm{~cm}^{-1}$. HRESIMS, $m / z$ calculated for $\mathrm{C}_{24} \mathrm{H}_{30} \mathrm{O}_{5} \mathrm{Si}[\mathrm{M}+\mathrm{H}]^{+}: 427.1938$. Found: 427.1946 .

\section{(3-((tert-Butyldimethylsilyl)oxy)-6,7-dimethoxyphenanthren-9- yl)methanol (10)}

To a cooled $\left(0{ }^{\circ} \mathrm{C}\right)$ solution of $9(110 \mathrm{~g}, 0.26 \mathrm{~mol})$ in dry $\mathrm{CH}_{2} \mathrm{Cl}_{2}$ $(1000 \mathrm{ml})$ was added DIBALH $(378 \mathrm{ml}, 0.57 \mathrm{~mol}, 1.5 \mathrm{M}$ in toluene) dropwise under argon, and the reaction mixture was allowed to stir at room temperature for $12 \mathrm{~h}$. Then the reaction mixture was quenched with $3 \mathrm{M} \mathrm{HCl}(550 \mathrm{ml})$ and extracted with $\mathrm{CH}_{2} \mathrm{Cl}_{2}(2 \times 500 \mathrm{ml})$. The combined organic layer was washed with brine $(1000 \mathrm{ml})$, dried with anhydrous $\mathrm{Na}_{2} \mathrm{SO}_{4}$, and concentrated under vacuum to furnish the product 10 (98 g, $0.25 \mathrm{~mol}$ ) with $95 \%$ yield, which was pure enough for the next step. ${ }^{1} \mathrm{H}$ NMR $\left(500 \mathrm{MHz}, \mathrm{CDCl}_{3}\right) \delta 7.84(\mathrm{~s}, 1 \mathrm{H}), 7.82(\mathrm{~d}, J=$ $2.2 \mathrm{~Hz}, 1 \mathrm{H}), 7.67$ (d, $J=8.6 \mathrm{~Hz}, 1 \mathrm{H}), 7.53(\mathrm{~s}, 1 \mathrm{H}), 7.47(\mathrm{~s}, 1 \mathrm{H})$, 7.08 (dd, $J=8.6,2.2 \mathrm{~Hz}, 1 \mathrm{H}), 5.03(\mathrm{~s}, 2 \mathrm{H}), 4.10(\mathrm{~s}, 3 \mathrm{H}), 4.02(\mathrm{~s}$, $3 \mathrm{H}), 1.06(\mathrm{~s}, 9 \mathrm{H}), 0.30(\mathrm{~s}, 6 \mathrm{H}) .{ }^{13} \mathrm{C} \mathrm{NMR}\left(125 \mathrm{MHz}, \mathrm{CDCl}_{3}\right)$ $\delta 154.5,149.4,148.9,131.7,131.4,130.1,125.9,125.7,124.9$, 124.6, 120.4, 111.4, 104.8, 103.8, 64.8, 56.0, 25.9, 18.5, -4.1. IR $(\mathrm{KBr}) \nu_{\max }=3368,2954,2932,2896,2857,1606,1524,1508$, 1423, 1390, 1361, 1268, 1204, 1159, 1112, 1078, 1033, 982, 921, $893,835,780 \mathrm{~cm}^{-1}$. HRESIMS, $m / z$ calculated for $\mathrm{C}_{23} \mathrm{H}_{30} \mathrm{O}_{4} \mathrm{SiNa}$ $[\mathrm{M}+\mathrm{Na}]^{+}:$421.1806. Found: 421.1823 .

\section{(S)-1-((3-Hydroxy-6,7-dimethoxyphenanthren-9-yl)methyl)-5- oxopyrrolidine-2-carboxylic acid (11)}

To the stirring mixture of alcohol 10 (98.0 g, $0.246 \mathrm{mmol}$ ), NaI (8.14 g, $53.3 \mathrm{mmol})$, 1,4-dioxane (400 ml), and MeCN $(600 \mathrm{ml})$ was added TMSCl $(46.8 \mathrm{ml}, 0.387 \mathrm{mmol})$ dropwise below $20^{\circ} \mathrm{C}$. After stirring $1 \mathrm{~h}$ at room temperature, anhydrous $\mathrm{K}_{2} \mathrm{CO}_{3}$ and dimethyl L-glutamate hydrochloride was added. When the reaction finished, it was filtered and acetic acid was added to the filtration. After completion of the reaction, the reaction was 
evaporated under vacuum to furnish the residue. The obtained residue was dissolved in methanol $(600 \mathrm{ml})$ and dichloromethane $(100 \mathrm{ml})$, and $4 \mathrm{M} \mathrm{NaOH}(240 \mathrm{ml})$ was added to the solution dropwise until the $\mathrm{pH}$ was stable around 11-12. After completion of the hydrolysis, most methanol was evaporated under reduced pressure. The obtained crude residue was mixed with $500 \mathrm{ml}$ water and then extracted with dichloromethane (3 $\times 500 \mathrm{ml}$ ). The aqueous phase was carefully acidified with $4 \mathrm{M}$ $\mathrm{HCl}$ to $\mathrm{pH} 2$ at $0-5{ }^{\circ} \mathrm{C}$ and off-white solid precipitated out of the reaction mixture. Simple filtration and baking of the solid afforded 11 (53.5 g, $0.135 \mathrm{~mol}$ ) with 55\% yield. Mp 190-192 ${ }^{\circ} \mathrm{C}$; ${ }^{1} \mathrm{H}$ NMR (500 MHz, CD 3 OD) $\delta 7.92(\mathrm{~s}, 1 \mathrm{H}), 7.83(\mathrm{~d}, J=2.1 \mathrm{~Hz}$, $1 \mathrm{H}), 7.69(\mathrm{~d}, J=8.6 \mathrm{~Hz}, 1 \mathrm{H}), 7.48(\mathrm{~s}, 1 \mathrm{H}), 7.44(\mathrm{~s}, 1 \mathrm{H}), 7.08(\mathrm{dd}, J$ $=8.6,2.1 \mathrm{~Hz}, 1 \mathrm{H}), 5.49(\mathrm{~d}, J=14.6 \mathrm{~Hz}, 1 \mathrm{H}), 4.30(\mathrm{~d}, J=14.6 \mathrm{~Hz}$, $1 \mathrm{H}), 4.03(\mathrm{~s}, 3 \mathrm{H}), 3.95(\mathrm{~s}, 3 \mathrm{H}), 3.78(\mathrm{dd}, J=9.4,3.3 \mathrm{~Hz}, 1 \mathrm{H}), 2.62-$ $2.55(\mathrm{~m}, 1 \mathrm{H}), 2.46-2.40(\mathrm{~m}, 1 \mathrm{H}), 2.19-2.13(\mathrm{~m}, 1 \mathrm{H}), 2.04-1.98$ (m, 1H). ${ }^{13} \mathrm{C}$ NMR (125 MHz, $\left.\mathrm{CD}_{3} \mathrm{OD}\right) \delta$ 177.5, 175.0, 157.8, $150.9,150.2$, 133.2, 131.2, 129.0, 127.0, 126.5, 126.1, 125.9, $117.5,106.7,106.1,105.3,60.0,56.5,56.3,45.6,30.95,23.8$. IR $(\mathrm{KBr}) \nu_{\max }=3240,2994,2966,2838,1742,1664,1634,1612$, 1581, 1532, 1511, 1443, 1391, 1359, 1320, 1159, 1122, 1064, 1030, 984, 880, 859, 841, $796 \mathrm{~cm}^{-1}$. HRESIMS, $m / z$ calculated for $\mathrm{C}_{22} \mathrm{H}_{20} \mathrm{NO}_{6}[\mathrm{M}-\mathrm{H}]^{-}:$394.1296. Found: 394.1308.

\section{(S)-3-Hydroxy-6,7-dimethoxy-13,13a-dihydrodibenzo[f,h] pyrrolo[1,2-b]isoquinoline-11,14 $(9 H, 12 H)$-dione (12)}

To the solution of $11(52.0 \mathrm{~g}, 0.132 \mathrm{~mol})$ in trifluoroacetic anhydride $(300 \mathrm{ml})$ was added boron fluoride ethyl ether (420 $\mathrm{ml}$ ) and the reaction was stirred for $30 \mathrm{~min}$ at $45{ }^{\circ} \mathrm{C}$. After completion of the reaction, it was poured to ice water $(1500 \mathrm{ml})$ and stirred for $1 \mathrm{~h}$ with light green precipitating out. Simple filtration and baking of the solid afforded $12(43.7 \mathrm{~g}, 0.116 \mathrm{~mol})$ with $85 \%$ yield. Mp $300{ }^{\circ} \mathrm{C}$ (decomposed); ${ }^{1} \mathrm{H}$ NMR $(500 \mathrm{MHz}$, DMSO- $\left.d_{6}\right) \delta 9.92(\mathrm{~s}, 1 \mathrm{H}), 9.13(\mathrm{~d}, J=9.2 \mathrm{~Hz}, 1 \mathrm{H}), 8.02(\mathrm{~d}, J=$ $2.5 \mathrm{~Hz}, 1 \mathrm{H}), 8.00(\mathrm{~s}, 1 \mathrm{H}), 7.48(\mathrm{~s}, 1 \mathrm{H}), 7.16(\mathrm{dd}, J=9.2,2.5 \mathrm{~Hz}$, $1 \mathrm{H}), 5.53(\mathrm{~d}, J=18.1 \mathrm{~Hz}, 1 \mathrm{H}), 4.80(\mathrm{~d}, J=18.1 \mathrm{~Hz}, 1 \mathrm{H}), 4.57(\mathrm{t}, J$ $=6.7 \mathrm{~Hz}, 1 \mathrm{H}), 4.07(\mathrm{~s}, 3 \mathrm{H}), 4.03(\mathrm{~s}, 3 \mathrm{H}), 2.48-2.29(\mathrm{~m}, 4 \mathrm{H}) .{ }^{13} \mathrm{C}$ NMR (125 MHz, DMSO- $\left.d_{6}\right) \delta 196.2,173.1,156.2,151.5,149.7$, $137.4,131.1,128.6,126.9$, 122.8, 122.3, 120.8, 117.5, 106.5, 105.2, 104.0, 60.8, 55.84, 55.79, 29.5, 20.4. IR (KBr) $\nu_{\max }=3167$, $3000,2925,2835,1708,1663,1613,1519,1457,1401,1353$, 1245, 1207, 1178, 1117, 1029, 940, 924, 844, 806, $760 \mathrm{~cm}^{-1}$. HRESIMS, $m / z$ calculated for $\mathrm{C}_{22} \mathrm{H}_{20} \mathrm{NO}_{5}[\mathrm{M}+\mathrm{H}]^{+}: 378.1336$. Found: 378.1335 .

(S)-3-((tert-Butyldimethylsilyl)oxy)-6,7-dimethoxy-13,13adihydrodibenzo $[f, h]$ pyrrolo $[1,2-b]$ isoquinoline-11,14 $(9 H, 12 H)$ dione (13)

To the stirring solution of $12(43.7 \mathrm{~g}, 0.116 \mathrm{~mol})$ and $N, N$-diisopropylethylamine $(45.0 \mathrm{~g}, 0.348 \mathrm{~mol})$ in DMF $(300 \mathrm{ml})$ was added TBSCl (34.9 g, $0.232 \mathrm{~mol})$. After completion of the reaction, water $(800 \mathrm{ml})$ was carefully added to the reaction dropwise. After it was stirred for additional $1 \mathrm{~h}$ at ice water bath, yellow solid precipitated. Simple filtration, washing by methanol and baking of the solid afforded 13 (48.2 g, $0.098 \mathrm{~mol}$ ) with 85\% yield. Mp 212-214 ${ }^{\circ} \mathrm{C} ;{ }^{1} \mathrm{H}$ NMR (500 MHz, $\left.\mathrm{CDCl}_{3}\right) \delta 9.27$ (d,
$J=9.2 \mathrm{~Hz}, 1 \mathrm{H}), 7.86(\mathrm{~d}, J=2.5 \mathrm{~Hz}, 1 \mathrm{H}), 7.85(\mathrm{~s}, 1 \mathrm{H}), 7.29(\mathrm{~s}, 1 \mathrm{H})$, $7.20(\mathrm{dd}, J=9.2,2.5 \mathrm{~Hz}, 1 \mathrm{H}), 5.70(\mathrm{~d}, J=17.8 \mathrm{~Hz}, 1 \mathrm{H}), 4.65(\mathrm{~d}, J$ $=17.8 \mathrm{~Hz}, 1 \mathrm{H}), 4.44-4.41(\mathrm{~m}, 1 \mathrm{H}), 4.15(\mathrm{~s}, 3 \mathrm{H}), 4.09(\mathrm{~s}, 3 \mathrm{H})$, 2.63-2.51 (m, 4H), 1.05 (s, 9H), $0.30(\mathrm{~s}, 6 \mathrm{H}) .{ }^{13} \mathrm{C}$ NMR $(125 \mathrm{MHz}$, $\left.\mathrm{CDCl}_{3}\right) \delta 195.5,174.2,154.6,151.7,149.9,137.4,131.4,129.1$, 127.7, 123.1, 122.8, 122.6, 121.6, 111.4, 104.3, 103.6, 61.2, 56.3, $56.1,40.7,30.2,25.9,21.0,18.5,-4.01,-4.02 . \mathrm{IR}(\mathrm{KBr}) \nu_{\max }=$ 3106, 2953, 2934, 2856, 1691, 1612, 1582, 1521, 1462, 1419, 1391, 1260, 1209, 1177, 1120, 1025, 953, 886, 825, $785 \mathrm{~cm}^{-1}$. HRESIMS, $m / z$ calculated for $\mathrm{C}_{25} \mathrm{H}_{34} \mathrm{NO}_{9}[\mathrm{M}+\mathrm{H}]^{+}: 492.2228$. Found: 492.2241. HPLC (Daicel Chiralpak OD-H, $4.6 \mathrm{~mm} \times 250$ $\mathrm{mml}, 10 \mu \mathrm{m}$, hexane $/ \mathrm{PrOH}=50: 50$, flow rate $=1 \mathrm{ml} \mathrm{min}^{-1}, \lambda$ $=264,355 \mathrm{~nm}): t_{\mathrm{R}}=25.9 \mathrm{~min} ; 99.5 \%$ ee.

\section{(S)-3-Hydroxy-6,7-dimethoxy-12,13,13a,14-tetrahydrodibenzo $[f, h]$ pyrrolo[1,2-b]isoquinolin-11(9H)-one (14)}

To the cooled solution of $13(48.2 \mathrm{~g}, 0.098 \mathrm{~mol})$ in dichloromethane $(200 \mathrm{ml})$ and methanol $(200 \mathrm{ml})$ was slowly added $\mathrm{NaBH}_{4}(11.1 \mathrm{~g}, 0.294 \mathrm{~mol})$. When the reaction finished, $1 \mathrm{M} \mathrm{HCl}$ was added to the reaction to make sure $\mathrm{pH}$ 7-8. After stirring for additional $1 \mathrm{~h}$, the reaction mixture was extracted into $\mathrm{CH}_{2} \mathrm{Cl}_{2}(3$ $\times 200 \mathrm{ml}$ ). The combined organic layer was concentrated under vacuum to furnish the intermediate. To a solution of the intermediate was added triethylsilane $(120 \mathrm{ml})$ and boron fluoride ethyl ether $(120 \mathrm{ml})$. After completion of the reaction, lots of off-white solid precipitated. Simple filtration, washing by dichloromethane and baking of the solid afforded $14(28.3 \mathrm{~g}$, $0.078 \mathrm{~mol})$ with $80 \%$ yield. Mp $257-259{ }^{\circ} \mathrm{C} ;{ }^{1} \mathrm{H}$ NMR $(500 \mathrm{MHz}$, DMSO- $\left.d_{6}\right) \delta 7.97(\mathrm{~d}, J=2.4 \mathrm{~Hz}, 1 \mathrm{H}), 7.95(\mathrm{~s}, 1 \mathrm{H}), 7.88(\mathrm{~d}, J=$ $9.0 \mathrm{~Hz}, 1 \mathrm{H}), 7.20$ (s, 1H), 7.12 (dd, $J=9.0,2.4 \mathrm{~Hz}, 1 \mathrm{H}), 5.09$ (d, $J$ $=17.2 \mathrm{~Hz}, 1 \mathrm{H}), 4.48(\mathrm{~d}, J=17.2 \mathrm{~Hz}, 1 \mathrm{H}), 4.00(\mathrm{~s}, 3 \mathrm{H}), 3.97(\mathrm{~s}$, $3 \mathrm{H}), 3.94-3.85$ (m, 1H), 3.45 (dd, $J=16.2,4.1 \mathrm{~Hz}, 1 \mathrm{H}), 2.80$ (dd, $J$ $=16.2,10.9 \mathrm{~Hz}, 1 \mathrm{H}), 2.48-2.35(\mathrm{~m}, 3 \mathrm{H}), 1.99-1.85(\mathrm{~m}, 1 \mathrm{H}) .{ }^{13} \mathrm{C}$ NMR (125 MHz, DMSO- $d_{6}$ ) $\delta$ 173.2, 155.8, 149.3, 148.4, 130.5, $125.7,125.2$, 124.2, 123.4, 122.7, 121.4, 116.4, 106.6, 104.1, 103.2, 55.53, 55.51, 52.4, 32.2, 29.4, 24.5. IR (KBr) $\nu_{\max }=3446$, 2946, 2835, 1660, 1618, 1519, 1470, 1441, 1358, 1272, 1202, 1169, 941, 864, $670 \mathrm{~cm}^{-1}$. HRESIMS, $\mathrm{m} / z$ calculated for $\mathrm{C}_{22} \mathrm{H}_{22} \mathrm{NO}_{4}[\mathrm{M}+\mathrm{H}]^{+}: 364.1543$. Found: 364.1543. HPLC (Daicel Chiralpak OD-H, $4.6 \mathrm{~mm} \times 250 \mathrm{mml}, 10 \mu \mathrm{m}$, hexane $/ \mathrm{iPrOH}=$

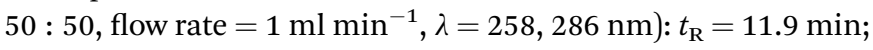
$99.5 \%$ ee.

\section{(S)-6,7-Dimethoxy-9,11,12,13,13a,14-hexahydrodibenzo[f,h] pyrrolo[1,2-b]isoquinolin-3-ol (PF403)}

To the cooled solution of $\mathbf{1 4}(28.3 \mathrm{~g}, 0.078 \mathrm{~mol})$ in THF $(200 \mathrm{ml})$ was added a solution of Red-Al (78 ml, $3.5 \mathrm{M}$ in toluene) in toluene under argon, and the reaction was stirred at room temperature until it finished. Then the reaction was cooled to $0{ }^{\circ} \mathrm{C}$ and the solution of seignette salt (78 $\mathrm{g}$ in $500 \mathrm{ml}$ water) was added along with stirring for additional 12-24 h. The precipitation was filtered and baked to afford PF403 (25.8 g, $0.074 \mathrm{~mol}$ ) as white solid with $95 \%$ yield. Mp $176-178{ }^{\circ} \mathrm{C} ;{ }^{1} \mathrm{H}$ NMR (500 MHz, DMSO- $\left.d_{6}\right) \delta 9.72(\mathrm{~s}, 1 \mathrm{H}), 7.95(\mathrm{~d}, J=2.2 \mathrm{~Hz}, 1 \mathrm{H}), 7.92(\mathrm{~s}$, $1 \mathrm{H}), 7.84(\mathrm{~d}, J=8.9 \mathrm{~Hz}, 1 \mathrm{H}), 7.18(\mathrm{~s}, 1 \mathrm{H}), 7.10(\mathrm{dd}, J=8.9$, $2.2 \mathrm{~Hz}, 1 \mathrm{H}), 4.53$ (d, $J=15.0 \mathrm{~Hz}, 1 \mathrm{H}), 3.99$ (s, 3H), 3.93 (s, 3H), 
3.64-3.57 (m, 1H), 3.50 (d, $J=15.0 \mathrm{~Hz}, 1 \mathrm{H}), 2.75$ (dd, $J=15.6$, $10.6 \mathrm{~Hz}, 1 \mathrm{H}), 2.36-2.31$ (m, 2H), 2.22-2.09 (m, 1H), 1.91-1.79 (m, 2H), 1.78-1.73 (m, 1H), 1.68-1.56 (m, 1H). ${ }^{13} \mathrm{C}$ NMR (125 MHz, DMSO- $\left.d_{6}\right) \delta 155.6,149.1,148.0,130.3,126.6,125.0,124.8$, 124.5, 123.8, 122.6, 116.3, 106.4, 104.0, 103.4, 59.9, 55.5, 55.4, 54.6, 53.4, 33.1, 30.9, 21.3. IR (KBr) $\nu_{\max }=3565,3092,2965$, 2825, 1626, 1585, 1535, 1511, 1481, 1461, 1437, 1414, 1386, 1359, 1323, 1256, 1237, 1150, 1033, 1009, 920, 844, $788 \mathrm{~cm}^{-1}$. HRESIMS, $m / z$ calculated for $\mathrm{C}_{22} \mathrm{H}_{24} \mathrm{NO}_{3}[\mathrm{M}+\mathrm{H}]^{+}: 350.1751$. Found: 350.1760. HPLC (Daicel Chiralpak AD-H, $4.0 \mathrm{~mm} \times 10$ $\mathrm{mml}, 5 \mu \mathrm{m}$, hexane (with $0.2 \% \mathrm{TEA}$ ) $/ \mathrm{iPrOH}=82: 18$, flow rate $=$ $\left.1 \mathrm{ml} \mathrm{min}{ }^{-1}, \lambda=258,287 \mathrm{~nm}\right): t_{\mathrm{R}}=14.6 \mathrm{~min} ; 99.6 \%$ ee.

\section{(13aS)-3-Pivaloyloxyl-6,7-dimethoxyphenanthro[9,10-b]- indolizidine (CAT3)}

To the cooled solution of PF403 (25.8 g, $0.077 \mathrm{~mol}$ ), triethylamine (34.5 ml, $0.23 \mathrm{~mol})$ and DMAP (0.94 g, $7.7 \mathrm{mmol})$ in dichloromethane $(300 \mathrm{ml})$ was added trimethylacetic anhydride $(28.1 \mathrm{~g}, 0.15 \mathrm{~mol})$. After completion of the reaction, it was quenched by water. The reaction mixture was extracted into dichloromethane $\mathrm{CH}_{2} \mathrm{Cl}_{2}(3 \times 200 \mathrm{ml})$. The combined organic layer was washed with brine $(3 \times 200 \mathrm{ml})$, dried with anhydrous $\mathrm{Na}_{2} \mathrm{SO}_{4}$, and concentrated under vacuum to furnish the residue, which was recrystallized by anhydrous ethanol $(400 \mathrm{ml})$ to afford CAT3 (22.4 g, $0.052 \mathrm{~mol}$ ) as off-white crystal with 70\% yield. Mp 200.4-200.8 ${ }^{\circ} \mathrm{C} ;{ }^{1} \mathrm{H}$ NMR (500 MHz, DMSO- $d_{6}$ ) $\delta 8.41$ $(\mathrm{s}, 1 \mathrm{H}), 8.07$ (s, 1H), 8.01 (d, $J=8.9 \mathrm{~Hz}, 1 \mathrm{H}), 7.29$ (d, $J=8.0 \mathrm{~Hz}$, $1 \mathrm{H}), 7.22(\mathrm{~s}, 1 \mathrm{H}), 4.58(\mathrm{~d}, J=15.3 \mathrm{~Hz}, 1 \mathrm{H}), 4.02(\mathrm{~s}, 3 \mathrm{H}), 3.94(\mathrm{~s}$, $3 \mathrm{H}), 3.53(\mathrm{~d}, J=15.3 \mathrm{~Hz}, 1 \mathrm{H}), 3.38-3.32(\mathrm{~m}, 2 \mathrm{H}), 2.87-2.73(\mathrm{~m}$, $1 \mathrm{H}), 2.37-2.31(\mathrm{~m}, 2 \mathrm{H}), 2.16-2.13(\mathrm{~m}, 1 \mathrm{H}), 1.85-1.81(\mathrm{~m}, 2 \mathrm{H})$, 1.68-1.59 (m, 1H), $1.40(\mathrm{~s}, 9 \mathrm{H}) .{ }^{13} \mathrm{C}$ NMR (125 MHz, DMSO- $\left.d_{6}\right)$ $\delta$ 176.9, 149.5, 148.8, 148.6, 129.6, 128.0, 127.8, 126.4, 124.9, $124.8,122.9,120.5,114.9,104.6,103.4,59.8,55.9,55.5,54.5$, 53.4, 38.7, 33.1, 30.8, 27.0, 21.3. IR (KBr) $\nu_{\max }=3097,2965$, 2830, 1740, 1619, 1530, 1510, 1468, 1427, 1415, 1367, 1339, 1256, 1205, 1164, 1135, 1034, 899, 841, 821, $786 \mathrm{~cm}^{-1}$. HRESIMS, $m / z$ calculated for $\mathrm{C}_{27} \mathrm{H}_{32} \mathrm{NO}_{4}[\mathrm{M}+\mathrm{H}]^{+}: 434.2331$. Found: 434.2332. HPLC [Daicel Chiralpak OZ-H, $4.6 \mathrm{~mm} \times 250 \mathrm{mml}, 5$ $\mu \mathrm{m}$, hexane (with $0.2 \% \mathrm{TEA}$ ) $/ \mathrm{iPrOH}=90: 10$, flow rate $=1$

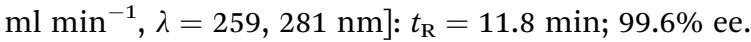

\section{Conclusions}

In summary, a novel and facile synthesis for CAT3 was achieved in 11 steps with $10 \%$ overall yield after multiple attempts. This route represents a very economical and practical synthesis, in which all the reactions and post treatments are easy to handle. Importantly, pilot-scale preparation has been achieved following this route, and it would be suitable for large-scale preparation. Based on preliminary studies of different substitutions at 3-position of phenanthrene, the relationship between the electronic effect of the 3-position substitute group and the enantiomeric excess of chiral intermediates and the final product has been preliminarily elucidated. The introduction of electron-donating group significantly retains the configuration of phenanthroindolizidine as $S$ at its 13a position. By virtue of the strong electron-donating TBS group, the excellent enantiomeric excess was achieved for CAT3 ( $\geq 99 \%$ ee) which is critical for its further preclinical investigations. This interesting finding not only represents a big breakthrough in the synthesis of CAT3, but also greatly inspires the construction and studies of chiral phenanthroindolizidine or other similar structures which is highly important for researchers in diverse fields, including natural product synthesis, organic chemistry, and medicinal chemistry.

\section{Conflicts of interest}

There are no conflicts to declare.

\section{Acknowledgements}

The authors are grateful to the Department of Instrumental Analysis of our institute for the acquisition of UV, IR, NMR, and MS spectra. This work was supported by grants from National Mega-project for Innovative Drugs (No. 2014ZX09304306-001), from CAMS Innovation Fund for Medical Sciences (No. 2016I2M-1-010) and from the Natural Science Foundation of China (No. 81602996).

\section{References}

1 P. M. Zeltzer, J. M. Boyett, J. L. Finlay, A. L. Albright, L. B. Rorke, J. M. Milstein, K. R. Stevens, P. Stanley, H. Li, J. H. Wisoff, J. R. Geyer, P. McGuire-Cullen, J. A. Stehbens, S. B. Shurin and R. J. Packer, J. Clin. Oncol., 1999, 17, 832.

2 J. M. Maris, M. D. Hogarty, R. Bagatell and S. L. Cohn, Lancet, 2007, 369, 2106.

3 M. R. Gilbert, E. P. Sulman and M. P. Mehta, N. Engl. J. Med., 2014, 370, 2048.

4 R. Bei, L. Marzocchella and M. Turriziani, Recent Pat. AntiCancer Drug Discovery, 2010, 5, 172.

5 V. A. Trinh, S. P. Patel and W. J. Hwu, Expert Opin. Drug Saf., 2009, 8, 493.

6 T. C. Johannessen and R. Bjerkvig, Expert Rev. Anticancer Ther., 2012, 12, 635.

7 J. Zhang, M. F. Stevens and T. D. Bradshaw, Curr. Mol. Pharmacol., 2012, 5, 102.

8 F. F. Yu, H. N. Lv, W. J. Dong, J. Ye, H. Z. Hao, S. G. Ma, S. S. Yu and Y. L. Liu, J. Pharm. Biomed. Anal., 2015, 107, 223.

9 Z. J. Liu, H. N. Lv, H. Y. Li, Y. Zhang, H. J. Zhang, F. Q. Su, S. Xu, Y. Li, Y. K. Si, S. S. Yu and X. G. Chen, Chemotherapy, 2011, 57, 310.

10 J. Chen, H. N. Lv, J. P. Hu, M. Ji, N. N. Xue, C. Li, S. G. Ma, Q. Zhou, B. Lin, Y. Li, S. S. Yu and X. G. Chen, Cancer Lett., 2016, 381, 391.

11 C. Li, Y. Li, H. Lv, S. W. Li, K. Tang, W. Q. Zhou, S. S. Yu and X. G. Chen, Internet J. Oncol., 2015, 47, 179.

12 M. Ji, L. Y. Wang, J. Chen, N. N. Xue, C. Y. Wang, F. F. Lai, R. B. Wang, S. S. Yu, J. Jin and X. G. Chen, OncoTargets Ther., 2018, 11, 3671.

13 H. N. Lv, J. H. Ren, S. G. Ma, S. Xu, J. Qu, Z. J. Liu, Q. Zhou, X. G. Chen and S. S. Yu, PLoS One, 2012, 7, e30342. 
14 H. N. Lv, S. Xu, S. G. Ma, Y. B. Liu, Y. Li, J. Qu, Z. J. Liu and S. S. Yu, Synthesis, 2015, 47, 1399.

15 P. F. Yu, H. N. Lv, C. Li, J. H. Ren, S. G. Ma, S. Xu, X. G. Chen and S. S. Yu, Synthesis, 2012, 44, 3757.

16 I. Takashi, Y. Takashi, M. Takeshi, Y. Ryuta, H. Syusuke and S. Seigo, Bioorg. Med. Chem. Lett., 2011, 21, 5978.

17 I. Takashi, S. Seigo, Y. Takashi, M. Takeshi, H. Shusuke and Y. Ryuta, PCT Int. Appl., 2010, 047127.
18 L. B. Liu, B. W. Yang, T. J. Katz and M. K. Poindexter, J. Org. Chem., 1991, 56, 3769.

19 R. B. Wang, S. S. Zhou, H. D. G. L. Jiang, X. G. Zheng, W. Zhou and S. S. Li, Eur. J. Org. Chem., 2012, 2012, 1373.

20 P. J. Kropp, G. W. Breton, S. L. Craig, S. D. Crawford, W. F. Durland, J. E. Jones and J. S. Raleigh, J. Org. Chem., 1995, 60, 4146.

21 S. Chandrasekhar, P. K. Mohanty, K. Harikishan and P. K. Sasmal, Org. Lett., 1999, 1, 877. 